\title{
PENGARUH RATIO KEUANGAN TERHADAP PREDIKSI PERTUMBUHAN LABA
}

\author{
Oleh \\ Indira Shinta Dewi.,SE.,MM.,Ak \\ Fakultas Ekonomi Program Studi Akuntansi \\ Universitas Satya Negara Indonesia
}

\begin{abstract}
ABSTRAK
Pertumbuhan laba sangat diharapkan oleh seluruh perusahaan. Pertumbuhan laba tidak bisa dipastikan secara pasti, oleh karena itu sangat diperlukan peramalan atau prediksi terhadap pertumbuhan laba . Prediksi dapat dilakukan dengan menganalisis laporan keuangan yaitu dengan menggunakan ratio keuangan. Beberapa penelitian terdahulu memberikan hasil penelitian yang berbeda terhadap prediksi pertumbuhan laba.

Tujuan penelitian ini adalah untuk mengetahui pengaruh ratio keuangan terhadap prediksi pertumbuhan laba pada perusahaan manufaktur yang terdaftar di Bursa Efek Indonesia tahun 2013-2015.Sampel penelitian ini menggunakan teknik purposive sampling. Berdasarkan kriteria diperoleh sampel observasi sebanyak 36 perusahaan. Data yang digunakan adalah data sekunder yang bersumber dari laporan keuangan perusahaan. Menggunakan analis regresi linier berganda untuk menganalisis data. Hasil uji parsial menunjukkan bahwa total assets turnover tidak berpengaruh terhadap prediksi pertumbuhan laba, current ratio tidak berpengaruh terhadap prediksi pertumbuhan laba, debt to assets ratio tidak berpengaruh terhadap prediksi pertumbuhan laba, debt to equity ratio, berpengaruh terhadap prediksi pertumbuhan laba.
\end{abstract}

Kata kunci: current ratio, debt to assets ratio, debt to equty ratio, pertumbuhan laba 


\section{PENDAHULUAN}

Kesuksesan perusahaan dapat dilihat dari kinerjanya, mengukur kinerja dari suatu perusahaan dapat terlihat dari pertumbuhan laba perusahaan tersebut. Laba merupakan angka penting dalam laporan keuangan karena berbagai alasan antara lain laba merupakan dasar dalam perhitungan pajak, pedoman dalam menentukan kebijakan investasi dan pengambilan keputusan, dasar dalam peramalan laba maupun kejadian ekonomi perusahaan lainnya di masa yang akan datang, dasar dalam perhitungan dan penilaian efisiensi dalam menjalankan perusahaan, serta sebagai dasar dalam penilaian prestasi atau kinerja perusahaan.

Disetiap periode, perusahaan akan selalu mengharapkan pertumbuhan laba dari periode sebelumnya, laba yang diperoleh perusahaan untuk tahun yang akan datang tidak bisa dipastikan secara pasti. Oleh karena itu perlu dilakukan prediksi atau peramalan pertumbuhan laba.

Beberapa temuan empiris menunjukkan bahwa rasio keuangan dapat memprediksi kebangkrutan, return saham, dan pertumbuhan laba. Penelitian ini dilakukan untuk menguji kembali hubungan rasio-rasio keuangan dengan pertumbuhna laba. Adanya ketidakkonsistenan membuat penulis tertarik untuk melakukan penelitian ulang. Penelitian dilakukan untuk memberikan bukti bahwa ratio keuangan berpengaruh terhadap prediksi pertumbuhan laba pada perusahaan manufaktur yang terdaftar di BEI tahun 2013- 2015.

Beberapa penelitian dibawah ini merupakan hasil dari penelitian terdahulu yang telah dilakukan oleh para peneliti sebelumnya degan hasil yang berbeda-beda.

Penelitian Gunawan dan Wahyuni (2013) dengan hasil penelitian secara parsial dapat diketahui variabel Total Asset Turnover berpengaruh secara signifikan terhadap pertumbuhan laba, sedangkan dalam penelitian Grisely (2015) menunjukkan hasil penelitiannya bahwa Total Asset Turnover tidak berpengaruh terhadap pertumbuhan laba. Total assets turnover merupakan perbandingan antara penjualan dengan total aktiva, dimana rasio ini menggambarkan kecepatan perputaran total aktiva dalam suatu periode tertentu". Tottal assets turnover mengukur efektivitas penggunaan seluruh aktiva dalam menghasilkan penjualan, semakin besar total penjualan dan total aktiva, berarti semakin efektif pengelolaan seluruh aktiva yang dimiliki perusahaan, maka labanya pun akan semakin meningkat, sehingga dapat dikatakan bahwa total asset turnover dapat memprediksi pertumbuhana laba.

Hasil penelitian Gunawan dan Wahyuni (2013) dapat diketahui variabel Current Ratio tidak berpengaruh terhadap pertumbuhan laba, sedangkan dalam penelitian Mahaputra (2012) menunjukkan hasil penelitiannya bahwa Current Ratio berpengaruh terhadap pertumbuhan laba. Current ratio mengukur kemampuan perusahaan untuk membayar utang lancar dengan menggunakan aktiva lancar yang dimiliki. Semakin besar current ratio maka semakin likuid perusahaan, maka pertumbuhan labanya pun akan semakin meningkat. Dapat dikatakan bahwa current ratio dapat memprediksi pertumbuhan laba.

Penelitian Gunawan dan Wahyuni (2013) dengan hasil penelitian variabel Debt to Equity Ratio tidak berpengaruh terhadap pertumbuhan laba, sedangkan dalam penelitian Mahaputra (2012) menunjukkan hasil penelitiannya bahwa Debt to Equity Ratio berpengaruh terhadap pertumbuhan laba. Debt to Equity Ratio merupakan rasio yang digunakan untuk 
menilai utang dengan ekuitas". debt to equity ratio yang semakin besar akan menurunkan laba perusahaan. Sehingga ratio ini dapat memprediksi pertumbuhan laba.

Penelitian ini bertujuan untuk menguji dan menemukan bukti empiris mengenai pengaruh rasio keuangan terhadap prediksi pertumbuhan laba pada perusahaan manufaktur sektor manufaktur yang tedaftar di Bursa Efek Indonesia.

Berdasarkan latar belakang yang telah diuraikan, maka dalam penelitian ini penulis mengambil judul "Pengaruh Rasio Keuangan Terhadap Prediksi Pertumbuhan Laba Pada Perusahaan Manufaktur yang Terdaftar di Bursa Efek Indonesia”.

\section{Tujuan dan Kegunaan Penelitian \\ Tujuan Penelitian}

1. Untuk mengetahui pengaruh Total Assets Turnover terhadap pertumbuhan laba pada perusahaan manufaktur yang terdaftar di Bursa Efek Indonesia..

2. Untuk mengetahui pengaruh Current Ratio terhadap pertumbuhan laba pada perusahaan manufaktur yang terdaftar di Bursa Efek Indonesia.

3. Untuk mengetahui pengaruh Debt to Assets Ratio pertumbuhan labapada perusahaan manufaktur yang terdaftar di Bursa Efek Indonesia.

4. Untuk mengetahui pengaruh Debt to Equity Ratio terhadap pertumbuhan laba pada perusahaan manufaktur yang terdaftar di Bursa Efek Indonesia.

\section{LANDASAN TEORI}

\section{Laba}

\section{Pengertian Laba}

IAI tidak menerjemahkan income dengan istilah laba, tetapi dengan istilah pengahasilan. PSAK No.23 menyebutkan dalam Konsep Dasar Penyusunan dan Penyajian Laporan Keuangan bahwa Penghasilan (income) adalah :

Peningkatan manfaat ekonomi selama suatu periode akuntansi dalam bentuk pemasukan atau penambahan aset atau penurunan kewajiban yang mengakibatkan kenaikan ekuitas, yang tidak berasal dari kontribusi penanam modal.

Harahap (2012:309) yang dimaksud dengan laba akuntansi itu adalah "perbedaan antara revenue yang direalisasi yang timbul dari transaksi pada periode tertentu dihadapkan dengan biaya-biaya yang dikeluarkan pada periode tersebut".

Menurut Kasmir (2012:302) "laba atau keuntungan merupakan salah satu tujuan utama suatu perusahaan dalam menjalankan aktivitasnya”. Pengertian laba secara operasional merupakan perbedaan antara pendapatan yang direalisasikan yang timbul dari transaksi selama satu periode dengan biaya yang berkaitan dengan pendapatan tersebut. 
Ukuran yang sering kali dipakai untuk menentukan sukses tidaknya manajemen perusahaan adalah laba yang diperoleh perusahaan. Berhasil atau tidaknya suatu perusahaan pada umumnya ditandai dengan kemampuan manajemen dalam melihat kemungkinan dan kesempatan di masa yang akan datang, baik jangka pendek maupun jangka panjang. Dengan demikian sasaran utama pelaporan keuangan yaitu informasi tentang prestasi-prestasi perusahaan yang disajikan melalui pengukuran laba dan sejauh mana laba tersebut dapat mengalami pertumbuhan ditahun-tahun berikutnya.

\section{Pertumbuhan Laba}

Pertumbuhan laba dapat dipakai untuk menganalisis kinerja perusahaan. Menurut Stice,et al (2004:225) Riset mendukung pernyataan FASB bahwa indikator terbaik atas kinerja adalah laba.

Menurut Ikatan Akuntansi Indonesia (2007) penghasilan bersih (laba) seringkali digunakan sebagai ukuran kinerja atau sebagai dasar bagi ukuran yang lain seperti imbalan investasi (return on investmen ) atau penghasilan per saham (earning per share).

Menurut Mahaputra (2012:249) "pertumbuhan laba dipengaruhi oleh perubahan komponen-komponen dalam laporan keuangan". Pertumbuhan laba yang disebabkan oleh perubahan komponen laporan keuangan misalnya perubahan penjualan, perubahan harga pokok penjualan, perubahan beban operasi, perubahan beban bunga, perubahan pajak penghasilan, adanya perubahan pada pos-pos luar biasa, dan lain-lain. Pertumbuhan laba dapat juga disebabkan oleh faktor-faktor luar seperti adanya peningkatan harga akibat inflasi dan adanya kebebasan manajerial yang memungkinkan manajer memilih metode akuntansi dan membuat estimasi yang dapat meningkatkan laba. Adapun formulasi dari pertumbuhan laba adalah sebagai berikut : Mahaputra (2012:249)

Pertumbuhan Laba $=$

Laba bersih tahun $\mathrm{t}$ - Laba bersih tahun $\mathrm{t}-1$

Laba bersih taun $\mathrm{t}-1$

Keterangan:

Laba bersih tahun $\mathrm{t}=$ Laba bersih tahun berjalan

Laba bersih tahun $\mathrm{t}-1$ = Laba bersih tahun sebelumnya 


\section{Analisis Rasio Keuangan}

\section{Pengertian Analisis Rasio Keuangan}

Rasio keuangan digunakan untuk mengevaluasi kondisi keuangan perusahaan dan kinerjanya. Dengan membandingkan rasio keuangan perusahaan dari tahun ke tahun dapat dipelajari komposisi perubahan dan dapat ditentukan apakah terdapat kenaikan atau penurunan kondisi dan kinerja perusahaan selama waktu tersebut. Selain itu, dengan membandingkan rasio keuangan terhadap perusahaan lainya yang sejenis atau terhadap ratarata industri dapat membantu mengidentifikasi adanya penyimpangan.

Menurut Kasmir (2012:104), "rasio keuangan merupakan indeks yang menghubungkan dua angka akuntansi dan diperoleh dengan membagi satu angka dengan angka yang lainnya dalam satu periode maupun beberapa periode".

Sedangkan Kieso dkk (2007:222) menyatakan bahwa informasi kualitatif dari laporan keuangan dapat dikumpulkan oleh para analis dan pihak yang berkepentingan lainnya dengan memeriksa hubungan antarpos-pos dalam laporan dan mengidentifikasi kecenderungan dalam hubungan ini. Titik awal yang baik dalam mengumpulkan informasi ini adalah analisis rasio.

\section{Klasifikasi Rasio Keuangan}

\section{Rasio Aktivitas}

Rasio aktivitas adalah rasio yang mengukur efektifitas perusahaan dalam memanfaatkan atau menggunkan sumber daya yang dimilikya. Rasio aktivitas sering juga disebut sebagai rasio efisiensi atau rasio pemanfaatan aktiva. Rasio ini menganggap bahwa sebaiknya terdapat keseimbangan yang layak antar penjualan dan berbagai unsur aktiva yaitu persediaan, piutang,aktiva tetap dan aktiva lainnya.

Rasio aktivitas menurut Van Horne (2005:212) adalah rasio yang mengukur seberapa efektif perusahaan menggunakan berbabagai aktivitasnya.

Rasio aktivitas menurut Kasmir (2012:172) adalah sebagai berikut :

Rasio aktivitas merupakan rasio yang digunakan untuk mengukur efektivitas perusahaan dalam menggunakan aktiva yang dimilikinya, atau dapat pula dikatakan rasio ini digunakan untuk mengukur tingkat efisiensi (efektivitas) pemanfaatan sumber daya perusahaan”.

Menurut Kasmir (2012:175), rasio aktivitas yang dapat digunakan manajemen untuk mengambil keputusan terdiri dari beberapa jenis. Secara umum apabila rasio aktivitas yang ada digunakan, akan mampu memperlihatkan efektifitas perusahaan secara maksimal, jika dibandingkan dengan hanya menggunakan sebagian saja. 


\section{Total Assets Turnover}

Total assets turnover menurut Sutrisno (2009:221) "merupakan ukuran efektifitas pemanfaatan aktiva dalam menghasilkan penjualan". Semakin besar perputaran aktiva semakin efektif perusahaan mengelola aktivanya. Rasio ini juga menunjukkan bagaimana sumber daya telah dimanfaatkan secara optimal.

Total Assets Turnover menurut Kasmir (2012:185), “merupakan rasio yang digunakan untuk mengukur perputaran semua aktiva yang dimiliki perusahaan dan mengukur berapa jumlah penjualan yang diperoleh dari tiap rupiah aktiva”. Rasio ini dapat menggambarkan seberapa efektif manajemen dalam mengelola semua aktiva perusahaan. Semakin cepat perputaran semua aktiva perusahaan maka semakin baik kinerja manajemen dalam mengelola semua aktiva perusahaan.

Rumus untuk menghitung total assets turnover menurut Kasmir (2012:186) adalah sebagai berikut :

\section{Total Assets Turnover $=$}

Penjualan Bersih

Total Aktiva

\section{Rasio Likuiditas.}

Rasio likuiditas digunakan untuk mengukur kemampuan perusahaan untuk memenuhi kewajiban keuangan jangka pendek tepat pada waktunya. Fungsi lain rasio likuiditas adalah untuk menunjukkan atau mengukur kemampuan perusahaan dalam memenuhi kewajiban yang jatuh tempo, baik kewajiban kepada pihak luar perusahaan maupun di dalam perusahaan

Menurut Kasmir (2012:130) rasio likuiditas sering juga disebut dengan rasio modal kerja yaitu "rasio yang digunakan untuk mengukur seberapa likuidnya suatu perusahaan". Caranya adalah dengan membandingkan komponen yang ada di necara, yaitu total aktiva lancar dengan total passiva lancar (untuk jangka pendek). Penilaian dapat dilakukan untuk beberapa periode sehingga terlihat perkembangan likuiditas perusahaan dari waktu ke waktu.

\section{Current Ratio}

Rasio lancar merupakan ukuran yang paling umum digunakan untuk mengetahui kesanggupan memenuhi kewajiban jangka pendek, oleh karena itu rasio tersebut menunjukan seberapa jauh tuntutan dari kreditor jangka pendek dipenuhi oleh aktiva yang diperkirakan menjadi uang tunai dalam periode yang sama dengan jatuh tempo hutang.

Menurut Kasmir (2012:134) rasio lancar (Current Ratio) merupakan "rasio untuk mengukur kemampuan perusahaan dalam membayar kewajiban jangka pendek atau utang yang segera jatuh tempo pada saat ditagih secara keseluruhan". Dengan kata lain, seberapa banyak aktiva yang tersedia untuk menutupi kewajiban jangka pendek yang akan segera jatuh tempo. Rasio lancar dapat pula dikatakan sebagai bentuk untuk mengukur tingkat keamanan (margin of safety) suatu perusahaan. Pengukuran rasio lancar dilakukan dengan cara membandingkan antara total aktiva lancar dengan total utang lancar. 
berikut :

Kasmir (2012:135) menyatakan bahwa Aktiva lancar dapat dirumuskan sebagai

$$
\text { Rasio lancar }(\text { Current Ratio })=\frac{\text { Aktiva Lancar }}{\text { Utang Lancar }}
$$

\section{Rasio Solvabilitas}

Rasio yang mengukur sejauh mana kemampuan perusahaan memenuhi kewajiban jangka panjangnya.

Rasio solvabilitas menurut Kasmir (2012:151) "merupakan rasio yang digunakan untuk mengukur sejauh mana aktivitas perusahaan dibiayai dengan utang”. Artinya seberapa besar beban utang yang ditanggung oleh perusahaan dibandingkan dengan jumlah aktiva yang dimilikinya. Dalam arti luas dikatakan bahwa rasio solvabilitas digunakan untuk mengukur kemampuan perusahaan untuk membayar seluruh kewajibannya, baik kewajiban jangka pendek maupun kewajiban jangka panjang apabila perusahaan dibubarkan (ilikuidasi).

\section{Debt to assets ratio}

Debt to assets ratio menurut Kasmir (2012:156) merupakan "rasio utang yang digunakan untuk mengukur perbandingan antara total utang dengan total aktiva". Dengan kata lain, seberapa besar aktiva perusahaan dibiayai oleh utang atau seberapa besar utang perusahaan berpengaruh terhadap pengelolaan aktiva.

Semakin tinggi rasio ini maka pendanaan dengan utang semakin banyak, sehingga semakin sulit bagi perusahaan untuk memperoleh tambahan pinjaman karena dikhawatirkan perusahaan tidak mampu menutupi utang-utangnya dengan aktiva yang dimilikinya. Sebaliknya semakin rendah rasio ini maka semakin kecil perusahaan dibiayai dari utang. Standar pengukuran untuk menilai baik tidaknya rasio perusahaan digunakan rasio rata-rata perusahaan yang sejenis.

Menurut Kasmir (2012:156) rumusan untuk mencari debt to assets ratio dapat digunakan sebagai berikut.

$$
\text { Debt to Assets Ratio }=\quad \frac{\text { Total Utang }}{\text { Total Aktiva }}
$$

Rasio tinggi berarti pendanaan dengan utang semakin banyak, maka semakin sulit bagi perusahaan untuk memperoleh tambahan pinjaman karena dikhawatirkan perusahaan tidak mampu menutupi utang-utangnya dengan aktiva yang dimilikinya. 
Semakin tinggi jumlah hutang lancar tentunya dapat meningkatkan total hutang perusahaan dan selanjutnya dapat meningkatkan debt to assets ratio, sehingga akan semakin banyak aktiva perusahaan akan dibelanjai oleh hutang. Hutang jangka panjang merupakan solusi untuk menambah modal perusahaan. Namun bila tidak di kelola dengan baik akan berdampak pada kemampuan perusahaan menghasilkan laba, karena meningkatnya beban bunga yang dimunculkan oleh hutang jangka panjang. Peningkatan hutang jangka panjang tentunya akan berdampak pada peningkatan total hutang perusahaan, sehingga akan semakin tinggi aktiva perusahaan dibelanjai oleh hutang. Tentunya hal ini akan berdampak negatif terhadap keberlangsungan perusahaan di masa mendatang.

\section{Debt to Equity Rasio}

Menurut Riyanto (2008:333), “debt to equity ratio digunakan untuk mengukur bagian dari setiap rupiah modal sendiri yang dijadikan jaminan untuk keseluruhan hutang”. Debt to Equity Ratio memberikan gambaran mengenai struktur modal yang dimiliki oleh perusahan, sehingga dapat dilihat tingkat risiko tidak tertagihnya suatu utang oleh para investor. Semakin besar nilai debt to equity ratio, maka akan menunjukkan tingginya ketergantungan permodalan perusahaan terhadap pihak luar sehingga beban perusahaan semakin berat, tentunya hal ini akan mengurangi pertumbuhan laba.

Menurut Kasmir (2012:157), "debt to equity ratio merupakan rasio yang digunakan untuk menilai utang dengan ekuitas". Untuk mencari rasio ini dengan cara membandingkan antara seluruh utang, termasuk utang lancar dengan seluruh ekuitas. Rasio ini berguna untuk mengetahui jumlah dana yang disediakan peminjam (kreditor) dengan pemilik perusahaan. Dengan kata lain rasio ini untuk mengetahui setiap rupiah modal sendiri yang dijadikan untuk jaminan utang.

Debt to equity ratio untuk setiap perusahaan tentu berbeda-beda, tergantung karakteristik bisnis dan keberagaman arus kasnya. Perusahaan dengan arus kas yang stabil biasanya memiliki rasio yang lebih tinggi dari rasio kas yang kurang stabil.

Menurut Kasmir (2012:158), rumus untuk mencari debt to equity ratio dapat digunakan perbandingan antara total utang dan total ekuitas sebagai berikut:

$$
\text { Debt to Equity Ratio }=\quad \frac{\text { Total Utang }}{\text { Total Ekuitas }}
$$

Besar-kecilnya rasio debt to equity ratio akan mempengaruhi tingkat pencapaian laba (Return On Equity) perusahaan. Semakin tinggi debt to equity ratio menunjukkan semakin besar beban perusahaan terhadap pihak luar, hal ini sangat memungkinkan menurunkan kinerja perusahaan, karena tingkat ketergantungan dengan pihak luar semakin tinggi. 


\section{Hubungan Rasio Keuangan dengan Prediksi Pertumbuhan Laba}

\section{Hubungan Total Aassets Turnover Ratio dengan Prediksi Pertumbuhan Laba}

Total asset turnover merupakan salah satu rasio aktivitas yang menunjukkan efisiensi penggunaan seluruh aktiva dalam memaksimalkan penjualan perusahaan. Semakin cepat perputaran aktiva suatu perusahaan untuk menunjang kegiatan penjualannya, artinya semakin efektif dan efisien seluruh penggunaan aktiva dalam menunjang kegiatan penjualan bersihnya, maka pendapatan yang diperoleh juga meningkat sehingga laba yang didapat semakin besar. Hal ini menunjukkan bahwa total asset turnover ratio dapat memprediksi pertumbuhan laba di masa yang akan datang.

H1: Total Assets Turnover berpengaruh terhadap pertumbuhan laba perusahaan Manufaktur yang terdaftar di Bursa Efek Indonesia

\section{Hubungan Current Ratio Terhadap Prediksi Pertumbuhan Laba}

Current ratio adalah salah satu rasio likuiditas yang mengukur kemampuan perusahaan membayar hutang jangka pendeknya dengan menggunakan aktiva lancar. Semakin besar Current Ratio maka semakin likuid perusahaan, maka pertumbuhan labanya pun akan semakin meningkat.

Apabila current ratio baik hal itu menunjukkan bahwa perusahaan dapat melunasi hutangnya saat jatuh tempo dengan menggunakan aktiva lancarnya. Setelah melunasi hutangnya perusahaan dapat kembali menggunakan aktiva lancar seperti untuk menambah persediaan yang digunakan untuk penjualan, penjualan meningkat maka laba tahun tersebut juga dapat meningkat. Maka dapat dikatakan bahwa current ratio dapat memprediksi pertumbuhan laba dapat memprediksi pertumbuhan laba di masa yang akan datang.

H2: Current Ratio berpengaruh terhadap prediksi pertumbuhan laba perusahaan Manufaktur yang terdaftar di Bursa Efek Indonesia.

\section{Hubungan Debt to Asset Ratio Terhadap Prediksi Pertumbuhan Laba}

Debt to Assets Ratio merupakan rasio utang yang digunakan untuk mengetahui seberapa besar aktiva perusahaan dibiayai oleh utang atau seberapa besar utang perusahaan berpengaruh terhadap pengelolaan aktiva.

Hal ini menunjukan bahwa perusahaan menggunakan alokasi dana dari utang untuk memaksimalkan kekayaan perusahaan. Namun dengan menggunakan dana dari utang akan meningkatkan resiko pada peningkatan beban bunga yang dibayarkan, sehingga hal ini akan berdampak pada penurunan laba. Hal ini menunjukkan bahwa Debt to Asset Ratio dapat memprediksi pertumbuhan laba di masa yang akan datang.

H3 Debt to Assets Ratio berpengaruh terhadap prediksi pertumbuhan laba perusahaan Manufaktur yang terdaftar di Bursa Efek Indonesia. 


\section{Hubungan Debt to Equity Ratio Terhadap Prediksi Pertumbuhan Laba}

Debt to equity ratio termasuk salah satu rasio solvabilitas yang menunjukkan perbandingan antara total hutang dengan total ekuitas, menggambarkan kemampuan modal perusahaan sendiri untuk memenuhi seluruh kewajibannya. Semakin tinggi debt to equity ratio berarti semakin besar pendanaan perusahaan dari kreditur sehingga resiko perusahaan juga semakin besar dan berdampak pada menurunnya laba perusahaan. Hal ini menunjukkan bahwa debt equity ratio dapat memprediksi pertumbuhan laba di masa yang akan datang.

H4 : Debt to Equity Ratio berpengaruh terhadap pertumbuhan laba perusahaan Manufaktur yang terdaftar di Bursa Efek Indonesia

\section{METODE PENELITIAN}

\section{Populasi dan Sampel}

Populasi dalam penelitian ini adalah perusahaan manufaktur yang terdaftar di Bursa Efek Indonesia (BEI) dari tahun 2013 sampai dengan tahun 2015. Berdasarkan IDX dari tahun 2013 sampai dengan tahun 2015 perusahaan manufaktur terdiri dari 430 perusahaan yang tercatat di Bursa Efek Indonesia (BEI). Sehingga populasi dalam penelitian ini adalah 430 perusahaan manufaktur yang terdaftar di Bursa Efek Indonesia.

Pengambilan sampel dengan menggunakan metode purposive sampling dengan kriteria sebagai berikut :

1. Perusahaan manufaktur yang terdaftar di Bursa Efek Indonesia (BEI) pada tahun 2013 sampai dengan 2015.

2. Perusahaan manufaktur yang terdaftar di Bursa Efek Indonesia (BEI) pada tahun 2013 sampai dengan 2015 yang mengalami pertumbuhan laba.

\section{Pengumpulan Data}

Ada dua cara metode pengumpulan data yang digunakan dalam penelitian ini yaitu

1. Metode Penelitian Kepustakaan (Library Research) adalah Penelitian dengan mengumpulkan data dengan cara membaca dan mempelajari buku-buku yang ada dan sumber data yang lainnya berkaitan dengan pembahasan masalah yang dibutuhkan.

2. Metode Penelitian Lapangan (Field Research) adalah metode dengan mengunjungi objek penelitian guna memperoleh data-data yang diperlukan untuk penyusunan penelitian tersebut. 


\section{Variabel Penelitian}

1. Variabel dependent (Y)

Variabel dependent yang digunakan dalam penelitian ini adalah prediksi pertumbuhan laba

2. Variabel independent (X)

Variabel bebas $(\mathrm{X})$ dalam penelitian ini adalah

$\mathrm{X} 1=$ Total Assets Turnover (TATO) (X1)

$\mathrm{X} 2=($ Current Ratio $(\mathrm{CR})$

$\mathrm{X} 3=$ Debt to Assets Ratio (DAR)

$\mathrm{X} 4=$ Debt to Equity Ratio (DER)

\section{Desain Penelitian}

Desain penelitian yang digunakan yaitu penelitian kausal yang merupakan penelitian untuk mengetahui pengaruh antara satu atau lebih variabel bebas (independent variable) terhadap variabel terikat (dependent variable). Peneliti ingin mengetahui rasio keuangan sebagai variabel bebas dalam memprediksi perubahan laba perusahaan manufaktur sebagai varibel terikat.

\section{Hipotesis}

Berdasarkan tinjauan pustaka dan penelitian terdahulu, maka penulis merumuskan hipotesis yang akan diuji kebenarannya sebagai berikut :

Ho1 : Total Asset Turnover tidak berpengaruh terhadap perubahan laba perusahaan manufaktur

Ha1 : Total Asset Turnover berpengaruh terhadap perubahan laba perusahaan manufaktur

Ho2: Current Ratio tidak berpengaruh terhadap perubahan laba perusahaan manufaktur

Ha2: Current Ratio berpengaruh terhadap perubahan laba perusahaan manufaktur

Ho3 : Debt to Assets Ratio tidak berpengaruh terhadap perubahan laba perusahaan manufaktur

Ha3 : Debt to Assets Ratio berpengaruh terhadap perubahan laba perusahaan manufaktur

Ho4 : Debt to Equity Ratio tidak berpengaruh terhadap perubahan laba perusahaan manufaktur

Ha4 : Debt to Equity Ratio berpengaruh terhadap perubahan laba perusahaan manufaktur 


\section{Kerangka Pemikiran}

Kerangka pemikiran dalam penelitian ini adalah sebagai berikut :

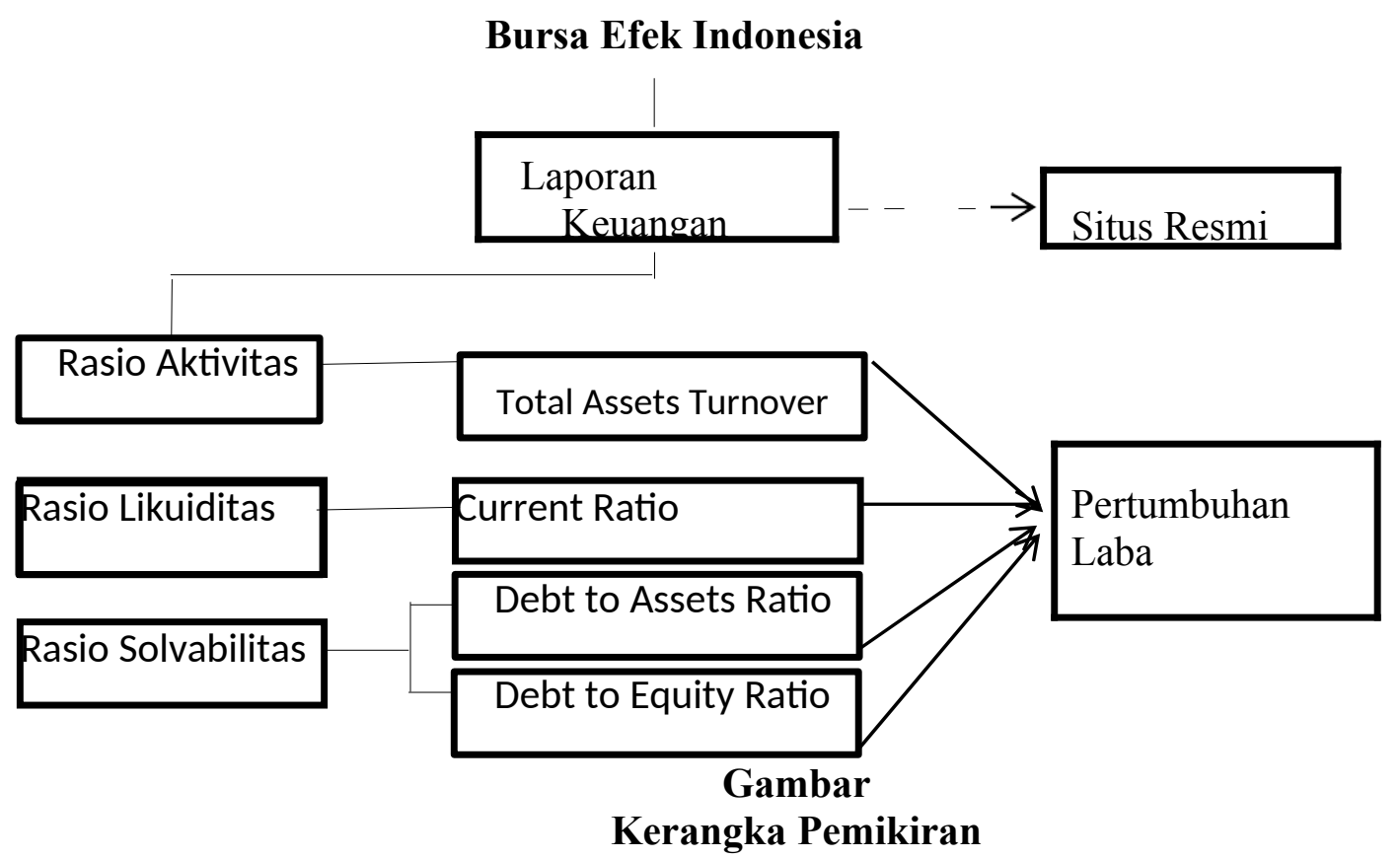

\section{Metode Analisis Data}

Metode analisis data yang digunakan dalam penelitian ini adalah analisis deskriptif dan analisis statistik:

\section{Analisis deskriptif}

Metode analisis deskriptif merupakan metode yang digunakan untuk menganalisis data-data yang tersedia dan diolah sehingga diperoleh gambaran yang jelas mengenai faktafakta fenomena yang diteliti.

Analisis deskriptif ini bertujuan untuk memberikan penjelasan mengenai variable yang digunakan dalam penelitian yang meliputi dependen $(\mathrm{Y})$ yaitu prediksi pertumbuhan laba manufaktur periode tahun 2013-2015 dan variable independen (X) yang digunakan yaitu Total Assets Turnover (TATO), Current Ratio (CR), Debt to assets ratio (DAR), Debt to equty ratio(DER)

\section{Analisis statistik}

Kebenaran hipotesis yang diajukan perlu dibuktikan dengan menggunakan uji regresi linier berganda. Beberapa tahapan yang dilakukan sebelum melakukan uji regresi linier berganda diperlukan uji asumsi klasik terlebih dahulu. 


\section{Uji Asumsi Klasik}

\section{Uji Normalitas}

Uji ini bertujuan untuk menguji apakah data yang digunakan telah terdistribusi normal. Model regresi yang baik adalah yang memiliki data terdistribusi normal. Menguji normalitas data, dapat dilihat pada grafik probability plot. Data dapat dikatakan normal bila data atau titik titik tersebar disekitar garis diagonal dan penyebarannya mengikuti garis diagonalnya. Metode yang lebih akurat untuk menguji normalitas adalah dengan uji Kolmogorov Smirnov, yaitu dengan melihat angka nilai signifikansinya lebih dari 0.05.

\section{Uji Multikolonieritas}

Uji multikolonieritas bertujuan untuk menguji apakah model regresi ditemukan adanya korelasi antar variabel bebas. Model regresi yang baik seharusnya tidak terjadi korelasi diantara variabel bebas. Untuk mendeteksi ada atau tidaknya gejala multikolinieritas dalam suatu model regresi dapat diketahui dengan kriteria Variance Inflation Factor (VIF) sebagai berikut:

1. Jika angka tolerance di bawah 0,10 dan $\mathrm{VIF} \geq 10$, dikatakan terdapat gejala multikolineritas.

2. Jika angka tolerance di atas 0,10 dan $\mathrm{VIF} \leq 10$, dikatakan tidak terdapat gejala multikolineritas.

\section{Uji Autokorelasi}

Uji autokorelasi bertujuan untuk menguji apakah dalam model regresi linier ada korelasi antara kesalahan pengganggu pada periode $\mathrm{t}$ dengan kesalahan pada periode $\mathrm{t}-1$ (sebelumnya). Model regresi yang baik adalah regresi yang bebas dari autokorelasi. Pengujian ada tidaknya autokorelasi dalam persamaan ini digunakan uji Durbin Watson (DW - test). Model regresi yang baik adalah model yang tidak mengandung autokorelasi.

Nilai uji statistik Durbin-Watson harus menunjukkan nilai 1-2 atau tidak boleh lebih dari tiga.

\section{Uji Heteroskedastisitas}

Menurut Ghozali (2016:134) "uji heterokedaktisistas bertujuan menguji apakah dalam model regresi terjadi ketidaksamaan variance dari residual satu pengamatan ke pengamata yang lain". Jika variance dari residual satu pengamatan ke pengamatan lain tetap, maka disebut Homoskedastisitas dan jika berbeda disebut Heteroskedastisitas. Model regresi yang baik adalah Homoskedastisitas atau tidak terjadi Heteroskedastisitas. 
Ada beberapa cara untuk mendeteksi ada atau tidaknya heteroskedastisitas yaitu :

1. Melihat Grafik Plot antara nilai prediksi variabel terikat (dependen) yaitu ZPRED segan residualnya SRESID.

Dasar analisis :

- Jikada pola tertentu, seperti titik-titik yang ada membentuk pola tertentu yang teratur (bergelombang, melebar kemudian menyempit), maka maka mengindikasikan telah terjadi heteroskedastisitas.

- Jika tidak ada pola yang jelas, serta titik-titik menyebar diatas dan dibawah angka nol pada sumbu Y, maka tidak terjadi heteroskedastisitas.

2. Uji Glejser

Menurut Ghozali (2016:137) uji glejser mengusulkan untuk meregres nilai absolut residual terhadap variabel independen. Jika tingkat signifikansinya $<0,5$ maka telah terjadi heteroskedatisitas, sebaliknya apabila tingkat signifikansinya $>0,5$ maka tidak terjadi heteroskedastisitas.

\section{Menilai Goodnes of Fit Suatu Model}

\section{Koefisien Determinasi $\left(\mathbf{R}^{2}\right)$}

Menurut Ghozali (2016:95) "koefisien determinasi $\left(R^{2)}\right.$ pada intinya mengukur seberapa jauh variabel independen dapat menjelaskan variabel dependen". Nilai $\mathrm{R}^{2}$ adalah 0 dan $1\left(0<\mathrm{R}^{2}<1\right)$, dimana suatu regresi yang baik akan menghasilkan nilai $\mathrm{R}^{2}$ yang tinggi. Hal ini berarti bahwa keseluruhan variabel bebas secara bersama-sama mampu menerangkan variabel terkaitnya. Sedangkan nilai $\mathrm{R}^{2}$ yang kecil berarti kemampuan variabel-variabel dependen sangat terbatas.

\section{Uji Regresi Linier Berganda}

Metode analisis regresi linear berganda merupakan suatu bentuk hubungan linear antara dua atau lebih variabel independen dengan variabel dependennya. Uji yang dilakukan dalam menganalisis penelitian ini adalah sebagai berikut:

\section{Uji F}

Uji ini merupakan pengujian untuk melihat pengaruh dari variabel-variabel independen secara simultan terhadap variabel dependen. Dalam pengujian ini sebelumnya dirumuskan hipotesisnya.

H0: Variabel-Variabel Independen secara simultan tidak berpengaruh terhadap variabel dependen

H1: Variabel- variabel Independen secara simultan berpengaruh terhadap variabel dependen

Kriteria pengujian untuk uji $\mathrm{F}$ berdasarkan signifikansi sebagai berikut :

Jika Signifikansi $>0,05$ maka $\mathrm{H} 0$ diterima

Jika Signifikansi $<0,05$ maka H0 ditolak 


\section{Uji t}

Digunakan untuk membuktikan pengaruh variabel independen terhadap variabel dependen secara individu atau parsial. Dalam pengujian ini sebelumnya dirumuskan hipotesisnya.

H0: Variabel Independen tidak berpengaruh terhadap variabel dependen

H1: Variabel Independen berpengaruh terhadap variabel dependen

Kriteria pengujian untuk uji t berdasarkan signifikansi sebagai berikut:

Jika Signifikansi $>0,05$ maka $\mathrm{H} 0$ diterima

Jika Signifikansi $<0,05$ maka H0 ditolak

\section{Persamaan Regresi Linier Berganda}

Model persamaan regresi berganda dalam penelitian ini adalah sebagai berikut:

$\mathrm{Y}=\mathrm{a}+\beta_{1} \mathrm{TATO}+\beta_{2} \mathrm{CR}+\beta_{43} \mathrm{DAR}+\beta_{4} \mathrm{DER}+\varepsilon$

Dimana :

\begin{tabular}{|c|c|}
\hline Y & $=$ Pertumbuhan laba \\
\hline TATO & $=$ Total Assets Turnover (TATO) \\
\hline $\mathrm{CR}$ & $=$ Current Ratio $(\mathrm{CR})$ \\
\hline DAR & $=$ Debt to Assets Ratio (DAR) \\
\hline DER & $=$ Debt to Equity Ratio (DER) \\
\hline$\beta_{1}, \beta_{2}, \beta_{3}, \beta_{4}$, & $=$ Koefisien regresi \\
\hline A & $=$ Konstanta \\
\hline$\varepsilon$ & $=$ Error term (variabel pengganggu) \\
\hline
\end{tabular}

ANALISIS HASIL DAN PEMBAHASAN

\section{Analisis Deskriptif}

\section{Descriptive Statistics}

\begin{tabular}{|l|r|r|c|}
\hline & \multicolumn{1}{|c|}{ Mean } & Std. Deviation & $\mathrm{N}$ \\
\hline Prediksi pertumbuhan laba & .4500 & .57355 & 36 \\
\hline Total asset turnover & 5.8358 & 20.35696 & 36 \\
\hline Current ratio & 148.6967 & 71.82805 & 36 \\
\hline Debt to assets ratio & .4928 & .22181 & 36 \\
\hline Debt to equity ratio & 1.1150 & .75466 & 36 \\
\hline
\end{tabular}

Sumber : Data Sekunder diolah 


\section{Analisis Statistik}

\section{Uji Asumsi Klasik}

\section{Uji Normalitas}

Uji Normalitas bertujuan untuk menguji apakah dalam suatu model regresi, variabel pengganggu atau residual memiliki distribusi normal. Melihat normalitas residual adalah dengan melihat normal probability plot. Uji normalitas yang digunakan dalam penelitian juga menggunakan uji Kolmogrov Smirnov. Data dikatakan berdistribusi normal jika nilai signifikansi yang diperoleh lebih besar dari nilai signifikansi yang ditetapkan sebelumnya yaitu $5 \%$

Hasil uji normalitas melalui program SPSS21 adalah sebagai berikut

\section{Hasil Uji Normalitas}

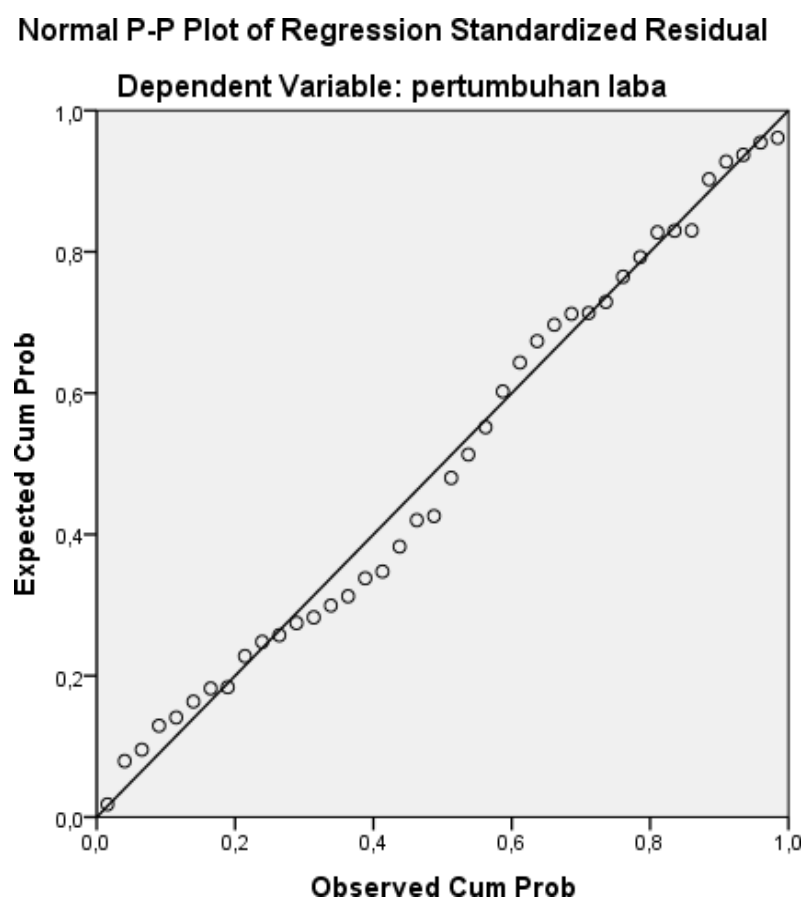

Sumber : Data Sekunder diolah

Berdasarkan gambar diketahui data menyebar disekitar garis diagonal dan mengikuti arah garis diagonal atau grafik histogramnya menunjukkan pola distribusi normal, naka model regresi memenuhi asumsi normalitas. 


\section{Hasil Uji Normalitas}

\begin{tabular}{|c|c|c|c|c|c|c|}
\hline & & $\begin{array}{l}\text { total } \\
\text { asset } \\
\text { turn } \\
\text { over }\end{array}$ & $\begin{array}{l}\text { current } \\
\text { ratio }\end{array}$ & $\begin{array}{l}\text { debt to } \\
\text { assets } \\
\text { ratio }\end{array}$ & $\begin{array}{l}\text { debt to } \\
\text { equity } \\
\text { ratio }\end{array}$ & $\begin{array}{l}\text { Prediksi } \\
\text { pertum } \\
\text { buhan } \\
\text { laba }\end{array}$ \\
\hline $\mathrm{N}$ & & 36 & 36 & 36 & 36 & 36 \\
\hline & Mean & 2,1768 & 3,0262 & 1,6896 & 1,9016 & 1,2433 \\
\hline Parameters $\mathrm{a}, \mathrm{b}$ & $\begin{array}{l}\text { Std. } \\
\text { Deviation }\end{array}$ & ,36277 & ,98424 &, 17326 & ,30184 & ,56877 \\
\hline & Absolute & , 194 &, 164 &, 058 &, 110 &, 141 \\
\hline Differences & Positive & ,194 & ,098 & ,058 &, 110 &, 141 \\
\hline & Negative &,- 137 &,- 164 &,- 056 &,- 083 &,- 092 \\
\hline Kolmogorov-S & irnov Z & 1,230 & 1,035 & 367 & ,696 & ,889 \\
\hline Asymp. Sig. (2 & ailed) & ,097 & ,234 & ,999 & ,718 & ,408 \\
\hline
\end{tabular}

Hasil uji Kolmogorov-Smirnov pada tabel menunjukkan nilai Kolmogorov-Smirnov sebesar 0,889 dengan tingkat probabilitas signifikansi sebesar 0,408. Nilai signifikan lebih dari 0,05 , maka dapat disimpulkan bahwa data residual terdistribusi secara normal. Dengan kata lain, model regresi yang digunakan memenuhi asumsi normalitas.

\section{Uji Multikolinearitas}

Uji Multikolinearitas bertujuan untuk menguji apakah model regresi berganda ditemukan adanya korelasi antar variabel bebas (independen).

Mendeteksi ada atau tidaknya multikolinearitas didalam model regresi dapat dilihat dari nilai Tolerance dan nilai Variance Inflation Factor (VIF). Model regresi yang baik adalah model regresi yang tidak terjadi korelasi diantara variabel bebas. Dapat diketahui dengan melihat nilai Variance Inflation Factor (VIF) jika VIF kurang dari 10 dan Tolerance lebih dari 0,1 maka dinyatakan tidak terjadi multikolinieritas. 


\section{Hasil Uji Multikolinearitas \\ Coefficients ${ }^{\mathrm{a}}$}

\begin{tabular}{|c|c|c|}
\hline \multirow[t]{2}{*}{ Model } & \multicolumn{2}{|c|}{ Collinearity Statistics } \\
\hline & Tolerance & VIF \\
\hline (Constant) & & \\
\hline total asset turnover & ,837 & 1,195 \\
\hline current ratio & ,938 & 1,066 \\
\hline debt to assets ratio & 422 & 2,369 \\
\hline debt to equity ratio & ,419 & 2,387 \\
\hline
\end{tabular}

a. Dependent Variable: pertumbuhan laba

Sumber : Data Sekunder diolah

Hasil perhitungan multikolinearitas dengan melihat nilai VIF, dapat ketahui bahwa untuk semua variabel mempunyai nilai VIF di bawah angka 10. Sehingga hasil uji multikolinearitas dengan VIF menunjukkan tidak adanya multikolinearitas antar variabel bebas, karena nilai VIF dibawah angka 10.

\section{Uji Heteroskedastisitas}

Model regrasi yang baik seharusnya tidak terjadi heteroskedastisitas. Uji heteroskedastisitas bisa dengan melihat pola titik-titik pada grafik regresi. Jika tidak ada pola yang jelas, seperti titik-titik menyebar di atas dan dibawah angka 0 pada sumbu Y, maka tidak terjadi heteroskedastisitas. Berikut grafik yang menunjukkan bahwa model regresi pada penelitian ini bebas dari gangguan heterokedastisitas

\section{Hasil Uji Heteroskedastisitas \\ Scatter Plot Standardized Residual vs Standardized Predic}

Scatterplot

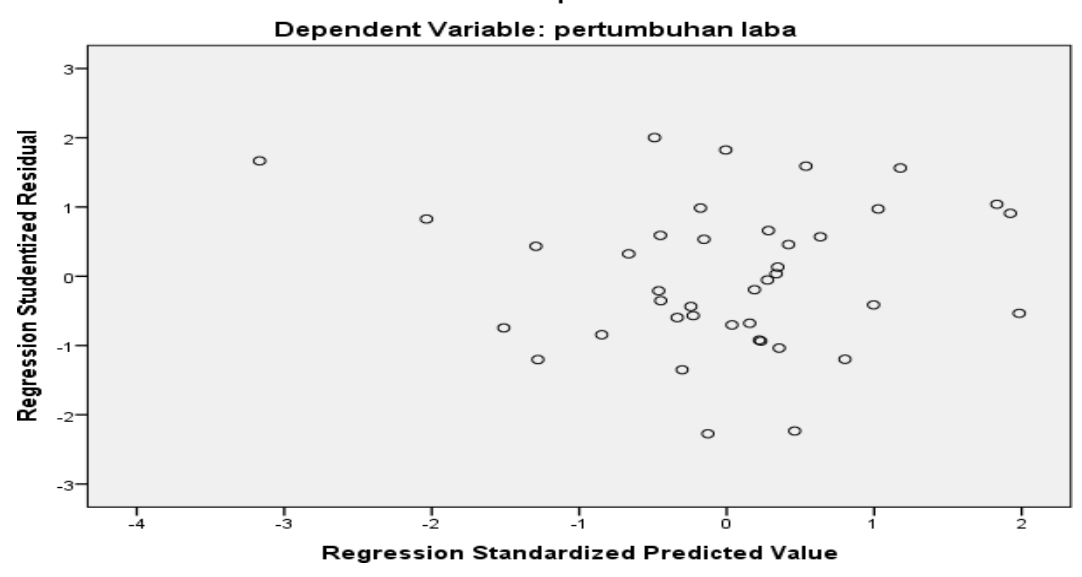

Sumber : Data Sekunder diolah 
Berdasarkan gambar dapat diketahui titik-titik yang ada tidak membentuk pola tertentu yang teratur (bergelombang, melebar kemudian menyempit) dan titik-titik menyebar di atas dan dibawah angka 0 pada sumbu Y, maka dapat disimpulkan bahwa model regresi tidak terjadi heteroskedastisitas. Selain menggunakan metode scatterplot, untuk lebih memastikan bahwa variabel-variabel tersebut terbebas dari heteroskedastisitas digunakan pula uji glejser pada tabel berikut

\section{Hasil Uji Glejser \\ Coefficients $^{\mathrm{a}}$}

\begin{tabular}{|c|c|c|c|c|c|}
\hline \multirow[t]{2}{*}{ Model } & \multicolumn{2}{|c|}{$\begin{array}{l}\text { Unstandardized } \\
\text { Coefficients }\end{array}$} & \multirow{2}{*}{$\begin{array}{c}\begin{array}{c}\text { Standardized } \\
\text { Coefficients }\end{array} \\
\text { Beta } \\
\end{array}$} & \multirow[t]{2}{*}{$\mathbf{T}$} & \multirow[t]{2}{*}{ Sig. } \\
\hline & $\mathbf{B}$ & Std. Error & & & \\
\hline (Constant) & ,230 &, 616 & & ,373 &, 711 \\
\hline $\begin{array}{l}\text { total asset } \\
\text { turnover }\end{array}$ &,- 127 & , 128 &,- 171 &,- 993 &, 528 \\
\hline current ratio &,- 003 & ,042 &,- 010 &,- 061 & ,952 \\
\hline $\begin{array}{l}\text { debt to } \\
\text { assets ratio }\end{array}$ & ,417 & ,337 & 298 & 1,239 & ,524 \\
\hline $\begin{array}{l}\text { debt to } \\
\text { equity ratio }\end{array}$ &,- 089 & , 196 &,- 111 &,- 457 & ,651 \\
\hline
\end{tabular}

a. Dependent Variable: abs

Sumber : Data Sekunder diolah

Dari tabel coefficients diatas uji glejser menunjukkan bahwa model penelitian tidak mengalami gangguan heterokedastisitas. Karena tingkat nilai signifikansinya diatas 0,50.

\section{Uji Autokolerasi}

Model regresi yang baik adalah model yang tidak mengandung autokorelasi. uji Durbin Watson (DW - test) digunakan untuk menguji autokorelasi. Nilai uji statistik DurbinWatson harus menunjukkan nilai 1-2 atau tidak boleh lebih dari tiga .

\section{Uji Autokorelasi}

\begin{tabular}{|c|c|c|c|c|c|c|c|c|c|}
\hline \multirow[t]{2}{*}{ Model } & \multirow[t]{2}{*}{$\mathrm{R}$} & \multirow{2}{*}{$\begin{array}{c}\mathrm{R} \\
\text { Squar } \\
\mathrm{e}\end{array}$} & \multirow{2}{*}{$\begin{array}{l}\text { Adjust } \\
\text { ed R } \\
\text { Square }\end{array}$} & \multicolumn{5}{|c|}{ Change Statistics } & \multirow{2}{*}{$\begin{array}{l}\text { Durbin- } \\
\text { Watson }\end{array}$} \\
\hline & & & & $\begin{array}{c}\mathrm{R} \\
\text { Square } \\
\text { Change }\end{array}$ & $\begin{array}{c}\text { F } \\
\text { Chan } \\
\text { ge }\end{array}$ & df1 & $\mathrm{df} 2$ & $\begin{array}{l}\text { Sig. F } \\
\text { Chan } \\
\text { ge }\end{array}$ & \\
\hline 1 & $\begin{array}{r}.4 \\
61 \\
\mathrm{a}\end{array}$ & .212 & .110 & .212 & 2,087 & 4 & 31 & .106 & 1.509 \\
\hline
\end{tabular}

a Predictors: (Constant), Arus Kas Operasi, Laba Kotor

b Dependent Variable: Return saham

Sumber: Data diolah dengan SPSS 
Berdasarkan tabel uji autokorelasi diatas terlihat bahwa nilai Durbin Watson sebesar 1,768. Ini berarti bahwa model regresi yang digunakan dalam penelitian sudah baik karena nilai Durbin Watson berada diantara nilai 1-2.

\section{Koefisien Determinasi $\left(R^{2}\right)$}

Koefisien determinasi $R^{2}$ bertujuan untuk mengukur seberapa jauh kemampuan model dapat menerangkan variasi variabel.

\section{R-Square pada Model Summary}

\begin{tabular}{|c|c|c|c|c|}
\hline Model & $\mathrm{R}$ & R Square & $\begin{array}{c}\text { Adjusted R } \\
\text { Square }\end{array}$ & $\begin{array}{c}\text { R Square } \\
\text { Change }\end{array}$ \\
\hline 1 & $.461^{\mathrm{a}}$ & .212 & .110 & .212 \\
\hline
\end{tabular}

Sumber: data diolah dengan SPSS

Dari tabel tersebut dapat terlihat bahwa Adjusted $R^{2}$ memiliki nilai sebesar 0,212 dapat disimpulkan bahwa model regresi mampu menjelaskan pengaruh variabel Total assets turnover, Current ratio, Debt to asstes ratio, Debt to equity ratio sebesar 21,2\% sedangkan sisanya $78,8 \%$ tidak dapat dijelaskan oleh persamaan regresi ini.

\section{Uji Linier Berganda}

Uji Simultan (Uji F)

Uji ini merupakan pengujian untuk melihat pengaruh dari variable-variabel independen secara simultan terhadap variabel dependen. Berikut adalah nilai $\mathrm{F}$ hitung dan signifikansi pada penelitian ini

\section{Uji Simultan (Uji F)}

ANOVA ${ }^{\mathrm{a}}$

\begin{tabular}{|l|l|r|r|r|r|r|}
\hline \multicolumn{2}{|l|}{ Model } & \multicolumn{1}{c|}{$\begin{array}{c}\text { Sum of } \\
\text { Squares }\end{array}$} & \multicolumn{1}{c|}{ Df } & $\begin{array}{c}\text { Mean } \\
\text { Square }\end{array}$ & F & Sig. \\
\hline \multirow{4}{*}{1} & Regression & 3,567 & 5 & .713 & 2,681 & $.038^{\mathrm{b}}$ \\
\cline { 2 - 7 } & Residual & 9,049 & 34 & .266 & & \\
\cline { 2 - 7 } & Total & 12,617 & 39 & & & \\
\hline
\end{tabular}

a. Dependent Variable: Prediksi pertumbuhan laba

b. Predictors: (Constant), Total assets turnover, Current ratio,Debt assets ratio, Debt equity ratio

Berdasarkan table diatas terlihat bahwa uji $\mathrm{F}$ ini mempunyai signifikansi sebesar 0,038. Nilai ini menunjukkan bahwa terdapat pengaruh Total assets turnover, Current ratio, Debt to assets ratio, Debt to equity ratio terhadap prediksi pertumbuhan laba pada perusahaan manufaktur di Bursa Efek Indonesia periode 2013-2015. 


\section{Uji Parsial (Uji t)}

Digunakan untuk membuktikan pengaruh variabel independen terhadap variabel dependen secara individu atau parsial. Untuk melihat hasil pengujian dapat dilihat pada table dibawah ini.

\section{Hasil Uji Parsial (Uji t)}

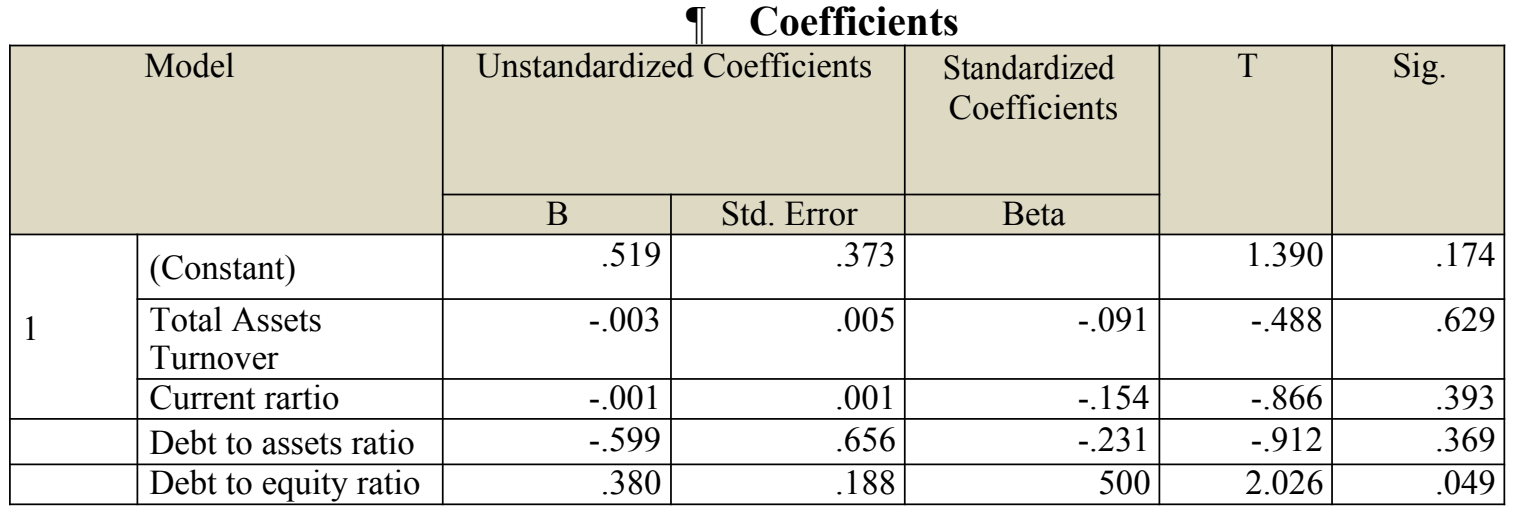

a. Dependent Variable: Prediksi pertumbuhan laba

Berdasarkan tabel diatas, maka dapat dijelaskan mengenai pengaruh secara parsial masing-masing variabel independen sebagai berikut :

\section{Pengaruh Total Assets Turnover (TATO) Terhadap Prediksi Pertumbuhan Laba}

Hasil pengujian statistik menunjukkan bahwa variable total assets turnover mempunyai nilai signifikansi sebesar 0,629 dengan koefisien regresi sebesar -0,003. Tingkat signifikan 0,629 yang memiliki nilai lebih besar dari tingkat signifikan $0,05(0,629>0,05)$. Hal ini menunjukkan bahwa " tidak ada pengaruh total assets turnover (TATO) terhadap prediksi pertumbuhan laba pada perusahaan manufaktur 2013-2015". Hal ini menyatakan bahwa $\mathrm{H} 0$ diterima

\section{Pengaruh Current Ratio (CR) Terhadap Prediksi Pertumbuhan Laba}

Hasil pengujian statistik menunjukkan bahwa variable current rasio mempunyai nilai signifikansi sebesar 0,393 dengan koefisien regresi sebesar -0,001. Tingkat signifikan 0,393 yang memiliki nilai lebih besar dari tingkat signifikan $0,05(0,393>0,05)$. Hal ini menunjukkan bahwa " tidak ada pengaruh current ratio (CR) terhadap prediksi pertumbuhan laba pada perusahaan manufaktur 2013-2015”. Hal ini menyatakan bahwa H0 diterima

\section{Pengaruh Debt to Assets Ratio (DAR) Terhadap Pertumbuhan Laba}

Hasil pengujian statistik menunjukkan bahwa variable current rasio mempunyai nilai signifikansi sebesar 0,363 dengan koefisien regresi sebesar -0,559. Tingkat signifikan 0,363 yang memiliki nilai lebih besar dari tingkat signifikan $0,05(0,363>0,05)$. Hal ini menunjukkan bahwa " tidak ada pengaruh Debt to Assets Ratio (DAR) terhadap Prediksi Pertumbuhan Laba pada perusahaan manufaktur 2013-2015". Hal ini menyatakan bahwa $\mathrm{H} 0$ diterima 


\section{Pengaruh Debt to Equity Ratio (DER) Terhadap Prediksi Pertumbuhan Laba}

Hasil pengujian statistik menunjukkan bahwa variable Debt to Equity Rasio (DER) mempunyai nilai signifikansi sebesar 0,049 dengan koefisien regresi sebesar -0,559. Tingkat signifikan 0,049 yang memiliki nilai lebih kecil dari tingkat signifikan $0,05(0,049$ $<0,05$ ). Hal ini menunjukkan bahwa " ada pengaruh debt to equity rasio (DER) terhadap prediksi pertumbuhan laba pada perusahaan manufaktur 2013-2015". Hal ini menyatakan bahwa $\mathrm{H} 0$ diterima

\section{Persamaan Regresi Linier Berganda}

Persamaan regresi linear berganda mempunyai tujuan untuk melakukan taksiran variasi nilai suatu variable terikat yang disebabkan oleh variasi nilai suatu variable bebas. Dengan demikian fungsi dari persamaan ini adalah untuk melakukan pendugaan terhadap variable terikat, apabila terjadi perubahan pada variable bebas yang dapat mempengaruhi variable terikat. Dalam mengolah data untuk menyusun model regresi ini digunakan program SPSS STATISTICS 21.

\section{Hasil Analisis Regresi Liner Berganda} Coefficients $^{\mathrm{a}}$

\begin{tabular}{|c|c|c|c|c|c|c|}
\hline \multirow{2}{*}{\multicolumn{2}{|c|}{ Model }} & \multicolumn{2}{|c|}{$\begin{array}{c}\text { Unstandardized } \\
\text { Coefficients }\end{array}$} & \multirow{2}{*}{$\begin{array}{c}\begin{array}{c}\text { Standardize } \\
\mathrm{d} \\
\text { Coefficients }\end{array} \\
\text { Beta }\end{array}$} & \multirow[t]{2}{*}{$\mathrm{t}$} & \multirow[t]{2}{*}{ Sig. } \\
\hline & & B & Std. Error & & & \\
\hline \multirow{5}{*}{1} & (Constant) & .519 & .373 & & 1.390 & .174 \\
\hline & $\begin{array}{l}\text { Total Assets } \\
\text { Turnover }\end{array}$ & -.003 & .005 & -.091 & -.488 & .629 \\
\hline & Current ratio & -.001 & .001 & -.154 & -.866 & .393 \\
\hline & $\begin{array}{l}\text { Debt to assets } \\
\text { ratio }\end{array}$ & -.599 & .656 & -.231 & -.912 & .369 \\
\hline & $\begin{array}{l}\text { Debt to equity } \\
\text { ratio }\end{array}$ & .380 & .188 & 500 & 2.026 & .049 \\
\hline
\end{tabular}

a. Dependent Variable: Prediksi pertumbuhan laba

Berdasarkan hasil pada table coefficient dapat disusun persamaan regresi linier berganda sebagai berikut:

Y(Prediksi Pertumbuhan Laba) $=0.519-0,003$ (TATO) $-0,001_{(\mathrm{CR})}-0,559_{(\mathrm{DAR})}$ $+\mathbf{0 , 3 8 0}(\mathrm{DER}) \mathrm{e}$

Dari persamaan regresi di atas dapat diinterprestasikan beberapa hal yaitu :

1. Nilai Constant sebesar 0,519 menyatakan bahwa jika variabel independen dianggap konstan, maka variabel dependent akan mengalami kenaikan sebesar 0,519.

2. Nilai koefisien regresi Total Assets Turnover (TATO) sebesar - $\mathbf{0 , 0 0 3}$ artinya adalah jika variabel lain nilainya tetap dan TATO mengalami kenaikan sebesar $1 \%$, maka prediksi pertumbuhan laba akan mengalami penurunan sebesar $0,003 \%$. 
3. Nilai koefisien regresi Current Ratio (CR) sebesar -0,001artinya adalah jika variabel independen lain nilainya tetap dan CR mengalami kenaikan sebesar $1 \%$, maka prediksi pertumbuhan laba akan mengalami penurunan sebesar $0,001 \%$.

4. Nilai koefisien regresi Debt To Assets Ratio (DAR) sebesar -0,559 artinya adalah jika variabel independen lain nilainya tetap dan DAR mengalami kenaikan sebesar 1\%, maka prediksi pertumbuhan laba akan mengalami penurunan sebesar $0,559 \%$.

5. Nilai koefisien regresi Debt To Equity Ratio (DER) sebesar 0,380 artinya adalah jika variabel independen lain nilainya tetap dan DER mengalami kenaikan sebesar $1 \%$, maka pertumbuhan laba akan mengalami kenaikan sebesar $0,380 \%$.

\section{Pembahasan dan Interprestasi \\ Hasil Penelitian dengan Landasan Teori dan Penelitian Terdahulu Pengaruh Total Assets Turnover terhadap Prediksi Pertumbuhan Laba}

Hasil analisis statistik menunjukkan bahwa total asset turnover secara parsial tidak berpengaruh terhadap pertumbuhan laba. Berarti bahwa perubahan yang ditunjukkan oleh total asset turnover tidak diikuti oleh peningkatan atau penurunan perubahan laba. Hasil penelitian ini tidak sesuai dengan teori yang menyatakan bahwa semakin cepat perputaran aktiva suatu perusahaan dapat meningkatkan laba perusahaan

Ketidakmampuan total asset turnover dalam mempengaruhi perubahan laba dimungkinkan karena kurang efektivitasnya perusahaan dalam menggunakan aktivanya untuk memaksimalkan penjualan sehingga tidak dapat mempengaruhi laba. Ketersediaan aset yang dimiliki perusahaan tidak dapat meningkatkan aktivitas operasional perusahaan terutama dalam hal kemampuan untuk meningkatkan pertumbuhan laba perusahaan. Penelitian memberikan hasil bahwa

total asset turnover tidak dapat memprediksi pertumbuhan laba

Hasil penelitian ini tidak sejalan dengan penelitian yang dilakukan oleh Gunawan, Wahyuni (2013), Mahaputra (2012) dengan hasil penelitian secara parsial yang menerangkan bahwa variabel Total Asset Turnover berpengaruh secara signifikan terhadap pertumbuhan laba.

\section{Pengaruh Current Ratio Terhadap Prediksi Pertumbuhan Laba}

Hasil SPSS menunjukkan bahwa current ratio secara parsial tidak berpengaruh terhadap prediksi pertumbuhan laba. Hal ini mengindikasikan bahwa perubahan yang ditunjukkan oleh current ratio tidak diikuti oleh peningkatan atau penurunan perubahan laba. Keseluruhan aktiva lancar yang dimiliki perusahaan dalam menutupi hutang jangka pendeknya belum mampu menghasilkan laba .Hasil penelitian ini tidak sesuai dengan teori yang menyatakan bahwa current ratio dapat memprediksi pertumbuhan laba.

Ketidakmampuan current ratio dalam memprediksi pertumbuhan laba karena efektivitas pengelolaan aktiva lancar yang dimiliki perusahaan kurang baik, sehingga aktiva lancar yang dimiliki tidak dapat meningkatkan aktifitas operasional perusahaan terutama dalam hal kemampuannya untuk membiayai utang lancar serta meningkatkan pertumbuhan laba perusahaan. Berarti bahwa current ratio tidak mempengaruhi pertumbuhan laba dikarenakan perusahaan bekerja secara tidak efektif dalam mengelola aktiva lancarnya 
Hasil penelitian ini tidak sejalan dengan penelitian yang dilakukan oleh Hartini (2012) dan Mahaputra (2012) dengan hasil penelitian secara parsial yang menerangkan bahwa variabel Current Ratio berpengaruh secara signifikan terhadap pertumbuhan laba.

\section{Pengaruh Debt to Assets Ratio terhadap Prediksi Pertumbuhan Laba}

Hasil SPSS menunjukkan bahwa secara parsial Debt to Assets Ratio tidak berpengaruh terhadap prediksi pertumbuhan laba. Hal ini mengindikasikan bahwa perubahan yang ditunjukkan oleh Debt to Assets Ratio tidak diikuti oleh peningkatan atau penurunan perubahan laba..

Efektivitas pengelolaan utang yang dimiliki perusahaan kurang baik, sehingga utang yang dimilki tidak dapat meningkatkan aktifitas operasional perusahaan terutama dalam hal kemampuan untuk meningkatkan pertumbuhan laba perusahaan. Aktiva yang diperoleh dari pendanaan luar tidak mampu untuk mempengaruhi laba yang diinginkan perusahaan. Perusahaan tidak bekerja secara efektif dan efisien dalam kegiatan operasional perusahaan untuk meningkatkan pertumbuhan laba yang bersumber dari utang.. Ini memiliki makna debt to assets ratio tidak bepengaruh terhadap pertumbuhan laba dikarenakan

Hasil penelitian ini sejalan dengan penelitian yang dilakukan oleh Wahyuni (2012) dengan hasil penelitian secara parsial yang menerangkan bahwa variabel Debt to Assets Ratio berpengaruh secara tidak signifikan terhadap pertumbuhan laba

\section{Debt to Equity Ratio dengan Prediksi Pertumbuhan Laba}

Hasil penelitian ini menunjukkan bahwa Debt to Equity Ratio berpengaruh positif terhadap prediksi pertumbuhan laba. Hal ini menunjukkan bahwa Debt to Equity Ratio yang tinggi dapat meningkatkan kemampuan memprediksi pertumbuhan laba dengan baik. Kemampuan ini karena kemampuan modal sendiri perusahaan untuk memenuhi seluruh kewajibannya sudah baik dan pengelolaan modal untuk menutupi utang dimanfaatkan dengan efektif perusahaan sehingga perusahaan mampu memperoleh kesempatan untuk meningkatkan laba dari pendanaan tersebut. Pendanaan dari kreditur dapat digunakan untuk operasional perusahaan dalam meningkatkan penjualan sehingga juga dapat meningkatkan perolehan laba.

Hasil penelitian ini sesuai teori yang menyatakan bahwa semakin tinggi debt to equity ratio berarti semakin besar pendanaan perusahaan dari kreditur dan apabila dimanfaatkan dengan efektif perusahaan juga memperoleh kesempatan untuk meningkatkan laba dari pendanaan tersebut.

Hasil penelitian ini sejalan dengan penelitian yang dilakukan oleh Wahyuni (2012), Hartini (2012) dengan hasil penelitian secara parsial yang menerangkan bahwa variabel Debt to Equity Ratio berpengaruh secara signifikan terhadap pertumbuhan laba. 


\section{KESIMPULAN}

1. Total Assets Turnover (TATO) tidak berpengaruh terhadap Prediksi Pertumbuhan Laba.

2. Current Ratio (CR) tidak berpengaruh terhadap Pertumbuhan Laba.

3. Debt to Assets Ratio (DAR) tidak berpengaruh terhadap Pertumbuhan Laba.

4. Debt to Equity Ratio (DER) berpengaruh terhahap Pertumbuhan Laba.

\section{SARAN}

1. Perusahaan yang digunakan dalam analisis data bisa menggunakan sektor lain selain sektor manufaktur atau menguji sub sektor perusahaannya saja.

2. Penelitian selanjutnya perlu menambah atau mengganti beberapa variabel yang dimungkinkan berpengaruh terhadap nilai perusahaan.

3. Faktor ekonomi seperti inflasi, tingkat suku bunga, kebijakan pemerintah dan lain sebagainya sebaiknya ikut dipertimbangkan sebagai penentu nilai variabel.

4. Memperpanjang periode penelitian sehingga memperbaiki hasil

\section{DAFTAR PUSTAKA}

\section{Daftar Buku:}

Akuntansi Indonesia. 2009. Standar Akuntansi Keuangan, Salemba Empat, Jakarta.

Darsono Purwanti Ari. 2010. Penganggaran Perusahaan edisi 2, Mitra Wacana Media. Jakarta

Ghozali, Imam. 2016. Aplikasi Analisis Multivariete IBM SPSS 23 edisi 8. Semarang: Universitas Diponegoro

Kasmir . 2012. Analisa Laporan Keuangan, Rajawali Pers, Jakarta

Keown Arthur j. dkk. 2008. Manajemen Keuangan Buku 1 edisi 10, Indeks, Indonesia.

Sudana Made I. 2011. Manajemen Keuangan Perusahaan edisi 2, Erlangga. Jakarta

Skousen, 2004 . Akuntansi Intermediate, Buku satu, Edisi kelima Belas,Salemba Emapat Jakarta

Van Horne, 2013. Prinsip-prinsip Manajemen Keuangan, Buku Satu,Edisi Kedua Belas, Salemba Empat Jakarta.

\section{Daftar Jurnal:}

Mahaputra Adnyana Kusuma Nyoman I. 2012. Pengaruh Rasio-Rasio Keuangan Terhadap Pertumbuhan Laba Pada Perusahaan Manufaktur Yang Terdaftar Di Bei, Universitas Mahasaraswati Denpasar.

Sayekti , Saputra Dwi Sumarno. 2015. Analisis Pengaruh Rasio Keuangan Terhadap Pertumbuhan Laba Pada Industri Rokok Yang Terdaftar Di Bursa Efek Indonesia, Universitas Slamet Riyadi Surakarta. 
Hartini Windi. 2012. Pengaruh Financial Ratio Terhadap Pertumbuhan Laba Dengan Pengungkapan Corporate Social Responsibility Sebagai Variabel Pemoderasi, Universitas Negeri Semarang.

Gunawan Ade, Wahyuni Fitri Sri. 2013. Pengaruh Rasio Keuangan Terhadap Pertumbuhan Laba Pada Perusahaan Perdagangan Di Indonesia, Universitas Muhammadiyah Sumatera Utara

Nisak Khoirun. 2015. Pengaruh Total Assets Turnover, Debt Ratio, Quick Ratio Dan Operating Income To Total Liability Terhadap Pertumbuhan Laba Pada Perusahaan Manufaktur Yang Terdaftar Di Bursa Efek Indonesia (Bei) Periode 2011 S/D 2013, Universitas Nusantara Pgri Kediri

www.sahamoke.com

www.idx.co.id 